\title{
EFEK PENGGUNAAN TEPUNG LIMBAH BIJI DURIAN FERMENTASI DALAM RANSUM AYAM BROILER TERHADAP PERFORMANS DAN INCOME OVER FEED COST (IOFC) AYAM BROILER
}

\author{
Dian Hidayatullah $^{1)}$, Yosi Fenita $^{2)}$, Endang Sulistiyowati ${ }^{2)}$ \\ ${ }^{1)}$ Program Pascasarjana Pengelolaan Sumber Daya Alam dan Lingkungan, Fakultas \\ Pertanian, Universitas Bengkulu \\ ${ }^{1)}$ Jurusan Peternakan Fakultas Pertanian Universitas Muhammadiyah Bengkulu \\ ${ }^{2)}$ Jurusan Peternakan Fakultas Pertanian Universitas Bengkulu
}

\begin{abstract}
ABSTRAK
Limbah biji durian selama ini belum begitu dimanfaatkan dan dibuang begitu saja. Biji durian sangat potensial dijadikan sumber pakan bagi ternak unggas karena kandungan nutrient yang baik. Pada beberapa penelitian terdahulu telah dilakukan teknologi pengukusan untuk menurunkan kandungan zat anti nutrisi, teknologi penepungan untuk memperpanjang masa simpan dan fermentasi untuk meningkatkan kualitas nutrisi. Tujuan penelitian ini adalah menyusun dan mengaplikasikan ransum komplit untuk ayam broiler dengan penambahan tepung biji durian fermentasi terhadap performans dan income over feed sost ayam broiler. Penelitian ini menggunakan 21-23 \% protein dengan kandungan energi metabolisme 2800-3000 Kkal/kg. Rancangan percobaan yang digunakan adalah Rancangan Acak Lengkap yang terdiri 4 perlakuan 5 ulangan. Perlakuan yang diuji adalah jenis ransum komplit yang ditambah dengan tepung biji durian fermentasi sebagai berikut : F0 : Ransum Kontrol; F1 : Ransum Kontrol dengan 7,5 \% Tepung biji durian fermentasi; F2 : Ransum Kontrol dengan $10 \%$ Tepung biji durian fermentasi; F3 : Ransum Kontrol dengan 12,5\% Tepung biji durian fermentasi; F4 : Ransum Kontrol dengan $15 \%$ Tepung biji durian fermentasi. Variabel yang diukur adalah Peformans Produksi : Pertambahan berat, Konsumsi ransum, Konversi Ransum dan IOFC. Hasil penelitian menunjukkan bahwa penggunaan tepung limbah biji durian fermentasi dalam ransum broiler sampai taraf $15 \%$ berpengaruh terhadap pertambahan berat badan dan nilai konversi ransum namun tidak berpengaruh terhadap konsumsi ransum, persentase karkas dan IOFC.
\end{abstract}

Kata Kunci : limbah biji durian, fermentasi, saccharomyces cerevisiae, ayam broiler, peformans, iofc

\section{PENDAHULUAN}

Merujuk pada definisi yang
tertuang dalam UU No 4 tahun 2009
tentang Pertambangan Mineral dan
Batubara, pascatambang diartikan sebagai
kegiatan setelah akhir sebagian atau
seluruh kegiatan usaha pertambangan
untuk memulihkan fungsi lingkungan dan
fungsi sosial. Untuk mewujudkan
pembangunan berkelanjutan, kegiatan
usaha pertambangan harus dilaksanakan
dengan memperhatikan prinsip lingkungan

hidup, transparansi dan partisipasi masyarakat. Prinsip pengelolaan lingkungan hidup meliputi perlindungan terhadap kualitas air permukaan, air tanah, air laut, dan udara sesuai dengan standar baku mutu lingkungan hidup dan ketentuan peraturan perundang-undangan.

Ketersediaan Jagung sebagai pakan utama sumber energi ternak unggas dewasa ini semakin sulit karena peralihan fungsi lahan untuk pemukiman, industri dan pembangunan fisik lainnya disamping itu penggunaan jagung sebagai pakan 
ternak dinilai kurang tepat disebabkan jagung juga merupakan sumber pangan kedua bagi manusia setelah beras. Pemanfaatan limbah merupakan sebuah alternatif untuk mengatasi masalah kesulitan bahan pakan. Salah satu limbah potensial untuk dimanfaatkan sebagai pakan sumber energi adalah limbah biji durian (Durio zibethinus Murr). Menurut (Zakaria, 2011) Selain digunakan sebagai bahan pakan, jagung saat ini banyak dimanfaatkan sebagai bahan baku biofuel dan sumber pangan.

Biji durian selama ini belum begitu dimanfaatkan dan dibuang begitu saja sebagai sampah. Biji durian sangat potensial dijadikan sumber pakan bagi ternak unggas karena kandungan nutrient yang baik khususnya karbohidrat dan protein. Kandungan gizi tepung biji durian (TBD) yang dikukus (Arsepto, 2004), lemak 1,56 persen, protein 9,95 persen, serat kasar 0,58 persen, abu 6,24 persen, BETN 81,67 persen dan energy metabolis sebesar 3604.13 kilokalori/ kilogram. Menurut Wahyono (2009) bahwa biji durian mengandung protein 9,79\%, karbohidrat $30 \%$, Kalsium $0,27 \%$ dan Pospor 0,9\%.

Populasi ayam ras broiler provinsi Bengkulu pada tahun 2013 adalah sebanyak 5.949.393 ekor terjadi penurunan populasi dari tahun 2010 yang jumlahnya adalah 6.449.002 ekor (Dinas Peternakan Provinsi Bengkulu, 2013), faktor utama terjadinya penurunan disebabkan sulitnya untuk mendapatkan bahan pakan yang sangat dibutuhkan bagi keberlanjutan usaha pokok peternakan.

Mengingat melimpahnya limbah biji durian serta sampai saat ini belum dimanfaatkan secara optimal dan bahkan sudah mulai menimbulkan dampak negatif ketika musim durian tiba sedangkan disisi lain limbah biji durian memiliki kualitas nutrisi yang baik yang dapat dimanfaatkan sebagai pakan ternak. Namun selain memiliki kandungan nutrisi yang baik, dalam pemanfaatan limbah biji durian terdapat beberapa faktor pembatas, yaitu kontinuitas ketersediaan, masa simpan dan adanya zat anti nutrisi yang dapat menghambat pertumbuhan ternak, pada beberapa penelitian terdahulu telah dilakukan teknologi pengukusan untuk menurunkan kandungan zat anti nutrisi, teknologi penepungan untuk memperpanjang masa simpan dan fermentasi untuk meningkatkan kualitas nutrisi.

Penelitian yang dilakukan oleh ( $\mathrm{Ri}-$ ta et al, 2014) memperoleh hasil terbaik dengan lama pengukusan 10 menit dan level penggunaan $10 \%$ dalam ransum ayam broiler, untuk itu dirasa sangat perlu mengetahui level penggunaan tepung limbah biji durian fermentasi dalam ransum ternak ayam broiler sehingga dapat dijadikan pakan alternatif ketika harga pakan komersial meningkat.

Tujuan penelitaian ini adalaha menyusun ransum komplit untuk ayam broiler dengan penambahan tepung biji durian fermentasi, mengaplikasikan ransum komplit dengan penambahan tepung biji durian fermentasi pada ayam broiler terhadap performans dan Income over feed cost (IOFC).

\section{METODE PENELITIAN}

\section{Waktu dan Tempat Pelaksanaan Penelitian}

Penelitian ini dilaksanakan pada Bulan April-November 2018 di Desa Sri Kuncoro Kabupaten Bengkulu Tengah. Analisa Proksimat dilakukan di Laboratorium Nutrisi dan Bahan Makanan Ternak Universitas Bengkulu.

\section{Bahan dan Alat Penelitian}

Bahan-bahan yang digunakan yaitu : ransum yang terdiri dari tepung biji durian fermentasi, jagung kuning giling, dedak padi halus, kosentrat broiler, mineral mix sesuai perlakuan, air dan ayam broiler.

Alat-alat yang dibutuhkan dalam penelitian ini adalah : kandang umbaran dengan lampu pemanas, kandang unit perlakuan, tempat pakan dan minum, 
terpal, timbangan analitik, ember, baskom, gelas piala kapasitas 2 liter, alat tulis, gunting, nampan, thermometer dan hygrometer.

\section{Rancangan Percobaan}

Penelitian ini menggunakan 21-22 $\%$ protein dengan kandungan energi metabolisme $\quad 3000-3100 \quad \mathrm{Kkal} / \mathrm{kg}$. Perlakuan yang diuji adalah jenis ransum komplit yang ditambah dengan tepung biji durian fermentasi sebagai berikut :

$\mathrm{F} 0=$ Ransum Kontrol, F1 = Ransum Kontrol dengan 7,5\% Tepung biji durian fermentasi, F2 = Ransum Kontrol dengan $10 \%$ Tepung biji durian fermentasi, F3 = Ransum Kontrol dengan 12,5 \% Tepung biji durian fermentasi, F4 = Ransum Kontrol dengan $15 \%$ Tepung biji durian fermentasi.

Tabel 1. Kandungan nutrisi bahan penyusun ransum broiler yang mengandung tepung biji durian fermentasi

\begin{tabular}{lcccccc}
\hline Bahan Pakan & $\begin{array}{c}\text { Protein } \\
\text { Kasar (\%) }\end{array}$ & $\begin{array}{c}\text { Lemak } \\
\text { Kasar }(\%)\end{array}$ & $\begin{array}{c}\text { Serat } \\
\text { Kasar }(\%)\end{array}$ & $\begin{array}{c}\text { EM } \\
(\mathrm{Kkal} / \mathrm{kg})\end{array}$ & $\begin{array}{c}\mathrm{Ca} \\
(\%)\end{array}$ & $\begin{array}{c}\mathrm{P} \\
(\%)\end{array}$ \\
\hline $\begin{array}{l}\text { Konsentrat Broiler*** } \\
\text { Jagung Kuning giling }\end{array}$ & 36 & 3,20 & 5,40 & 2800 & 2,72 & 1,45 \\
$*$ & 8.20 & 0.75 & 2.24 & 3340 & 0,02 & 0,23 \\
$\begin{array}{l}\text { Tepung Biji Durian } \\
\text { Fermentasi ** }\end{array}$ & 5,99 & 0,61 & 1,27 & 3400 & - & - \\
$\begin{array}{l}\text { Dedak Halus * } \\
\text { Mineral Mix }\end{array}$ & 10.8 & 6.96 & 21.54 & 1900 & 0,1 & 1,3 \\
Top Mix & - & - & - & - & 32 & 10 \\
Keterangan : * : Bahan dianalisa di Laboratorium Ilmu dan Tekhnologi Pakan IPB & Bogor dan Laboratorium \\
& $\begin{array}{l}\text { Nutrisi Ternak Perah Institut Pertanian Bogor (Rita et al, 2014) **: Bahan dianalisa di } \\
\text { Laboratorium Nutrisi dan Bahan Makanan Ternak Universitas Bengkulu (Malianti, 2018), }\end{array}$ \\
: Pt. Jafpa Comfeed.
\end{tabular}

Tabel 2. Susunan ransum masing-masing perlakuan.

\begin{tabular}{lccccc}
\hline \multirow{2}{*}{ Bahan Pakan } & \multicolumn{5}{c}{ Perlakuan } \\
\cline { 2 - 6 } & F0 (kontrol) & F1 (7,5\%) & F2 (10\%) & F3 (12,5\%) & F4 (15\%) \\
\hline Kosentrat Broiler & 55 & 55 & 55 & 55 & 55 \\
Jagung kuning giling & 35 & 27,5 & 25 & 22,5 & 20 \\
TBDF & 0 & 7,5 & 10 & 12,5 & 15 \\
Dedak & 10 & 10 & 10 & 10 & 10 \\
\hline Total & 100 & 100 & 100 & 100 & 100 \\
\hline Suplementasi & 1 & & & & \\
\hline Mineral Mix & 1 & 1 & 1 & 1 & 1 \\
Top Mix & 0,5 & 0,5 & 0,5 & 0,5 & 0,5 \\
\hline
\end{tabular}


Tabel 3. Kandungan Nutrisi Ransum Percobaan

\begin{tabular}{|c|c|c|c|c|c|}
\hline \multirow[t]{2}{*}{ Kandungan Gizi } & \multicolumn{5}{|c|}{ Perlakuan } \\
\hline & $\begin{array}{c}\text { F0 } \\
\text { (kontrol) }\end{array}$ & F1 $(7,5 \%)$ & F2 $(10 \%)$ & F3 $(12,5 \%)$ & $\mathrm{F} 4(15 \%)$ \\
\hline Protein $(\%)$ & 23,52 & 23,35 & 23,30 & 23,24 & 23,19 \\
\hline Lemak Kasar (\%) & 3,59 & 3,33 & 3,25 & 3,16 & 4,86 \\
\hline Serat Kasar (\%) & 5,05 & 4,95 & 4,92 & 4,89 & 3,07 \\
\hline ME (Kkal/kg) & 2858,00 & 2865,50 & 2868,00 & 2870,50 & 2873,00 \\
\hline $\mathrm{Ca}(\%)$ & 1,51 & 1,51 & 1,51 & 1,51 & 1,51 \\
\hline $\mathrm{P}(\%)$ & 1,01 & 0,99 & 0,99 & 0,98 & 0,97 \\
\hline $\begin{array}{l}\text { Rancangan } \\
\text { digunakan adalah } \\
\text { Lengkap (RAL) denga } \\
\text { ulangan, masing-mas } \\
\text { sehingga diperlukan 10 } \\
\text { dan Torrie (1991). } \\
\text { dianalisis variansnya } \\
\text { diuji F untuk me } \\
\text { perlakuan. Jika ada }\end{array}$ & $\begin{array}{l}\text { percobaan } \\
\text { Rancangan } \\
\text { in } 5 \text { perlakuar } \\
\text { ing diisi } 5 \\
0 \text { ekor ayam. } \\
\text { Data yang dir } \\
\text { (ANOVA) } \\
\text { ngetahui pe } \\
\text { pengaruh per }\end{array}$ & $\begin{array}{r}\text { yang } \\
\text { Acak } \\
\text { n dan } 4 \\
5 \text { ekor } \\
\text { Steel } \\
\text { peroleh } \\
\text { dengan } \\
\text { engaruh } \\
\text { rlakuan }\end{array}$ & $\begin{array}{l}\text { mencapai } 6 \\
\text { durian yang } \\
\text { dimasukkan } \\
\text { ditutup rap } \\
\text { jam, pada } \\
\text { durian diker } \\
\text { dibawah s } \\
\text { tepung biji } \\
\text { digunakan } \\
\text { jagung dala1 }\end{array}$ & $\begin{array}{l}\text { diaduk hingg } \\
\text { elah diinokulas } \\
\text { e dalam kantor } \\
\text { dan didiamka } \\
\text { hap akhir fe } \\
\text { gkan dengan c } \\
\text { ar matahari. } \\
\text { durian yang } \\
\text { bagai pengga } \\
\text { formulasi ransu }\end{array}$ & $\begin{array}{l}\text { merata. Biji } \\
\text { dengan ragi } \\
\text { plastik dan } \\
\text { selama } 48 \\
\text { entasi biji } \\
\text { a menjemur } \\
\text { Selanjutnya } \\
\text { lah kering } \\
\text { i sebagian } \\
\text { broiler. }\end{array}$ \\
\hline
\end{tabular}

yang signifikan dilanjut dengan uji DMRT (Duncan's Multiple Range Test).

\section{Prosedur Penelitian \\ Pembuatan Tepung Biji Durian}

Biji durian terlebih dahulu dikumpulkan, disortir, dicuci, dikukus selama 10 menit, diiris tipis, dijemur dan digiling menjadi tepung.

\section{Pembuatan Tepung Biji Durian \\ Fermentasi}

Limbah biji durian yang digunakan dalam penelitian ini difermentasi dengan ragi tape (Saccharomices cereveseae) Prosedur fermentasi dilakukan berdasarkan petunjuk Ciptadi dan Nasution (1980), tahap pertama Fermentasi ini adalah dengan cara mengukus tepung biji durian menggunakan panci pengukus sederhana selama 30 menit. Selanjutnya biji durian yang sudah dikukus didinginkan sampai mencapai suhu kamar. Inokulasi dilakukan dengan mencampurkan 7,5\% ragi tape dari berat biji durian, ditambahkan aquades hingga kadar air

\section{Persiapan Ransum}

Ransum disusun setiap minggu dengan menghitung kebutuhan standar ayam broiler sesuai perlakuan dengan tahapan menimbang bahan-bahan yang dibutuhkan kemudian mencampur seluruh bahan.

\section{Pemeliharaan Ayam}

Ayam yang digunakan adalah strain Lohman platinum MB AI 202 (DOC) sebanyak 100 ekor, yang dipelihara dalam kandang umbaran selama 2 minggu dengan diberi ransum komersil (BR1), kemudian pada umur 15 hari ayam dipindahkan ke kandang unit percobaan yang masing-masing unit diisi oleh 5 ekor ayam. Untuk mencegah timbulnya penyakit, ayam divaksin dengan vaksin ND Lasota pada umur 4 hari dan divaksin dengan vaksin gumboro pada umur 14 hari, sedangkan untuk mencegah stress digunakan Vitachick. Pada minggu ketiga ayam dipindahkan kekandang unit percobaan, pada kandang ini ayam 
dipelihara selama 4 minggu diberi ransum perlakuan, setiap pagi dan sore hari ransum yang tercecer dan sisa ransum ditimbang. Tempat pakan dan minum dibersihkan. Air minum tersedia secara adlibitum yang diberikan bersamaan dengan pemberian ransum.

Penimbangan ayam dilakukan seminggu sekali. Pemotongan ayam dilakukan pada akhir minggu kelima penelitian (umur 42 hari), yaitu diambil secara acak satu ekor ayam untuk setiap unit kandang yang telah dipuasakan selama 12 jam. Pengambilan sampel darah dilakukan melalui pembuluh vena brachialis dengan spuit, darah diambil minimal $1 \mathrm{ml}$ dan ditampung dalam tabung EDTA, setelah pengambilan sampel darah kemudian ayam ditimbang dan dicatat sebagai berat badan akhir. Untuk mendapatkan bobot karkas dapat diketahui setelah isi saluran pencernaan kecuali ginjal dan paru-paru dikeluarkan, kepala dipotong pada batas tulang atlas dan kaki dipotong pada batas persendian.

\section{Variabel yang diukur}

Pertambahan berat badan (PBB) dihitung dengan rumus sebagai berikut : $\mathrm{BB}$ akhir minggu - BB minggu sebelumnya. Konsumsi ransum: jumlah ransum yang diberikan (gr) - jumlah ransum yang tersisa (gr). Konversi ransum = Konsumsi ransum selama penelitian (gr) I Pertambahan berat badan selama penelitian (gr). Income over feed cost dihitung berdasarkan perbandingan antara pendapatan yang diperoleh dari penjualan ayam dan biaya ransum selama pemeliharaan (Rasyaf, 2011).

\section{HASIL DAN PEMBAHASAN}

Rata-rata konsumsi ransum, pertambahan bobot badan, konversi ransum, persentase karkas dan IOFC disajikan pada tabel berikut.

Tabel 4. Konsumsi ransum, pertambahan bobot badan, dan konversi ransum ayam broiler selama penelitian.

\begin{tabular}{lrrrrrr}
\hline \multicolumn{1}{c}{ Variabel } & F0 (kontrol) & F1 (7,5\%) & F2 (10\%) & F3 (12,5\%) & F4 (15\%) & P \\
\hline $\begin{array}{l}\text { Konsumsi Ransum } \\
\text { (g/ekor) }\end{array}$ & $3.140,00$ & $3.170,00$ & $3.027,00$ & $3.147,00$ & $3.062,00$ & $\mathrm{~ns}$ \\
$\begin{array}{l}\text { Berat Badan Awal } \\
\text { (g/ekor) }\end{array}$ & 528,00 & 535,00 & 485,00 & 520,00 & 505,00 & - \\
$\begin{array}{l}\text { Berat Badan Akhir } \\
\text { (g/ekor) }\end{array}$ & $1.905,00$ & $1.833,00$ & $1.755,00$ & $1.730,00$ & $1.683,00$ & $\mathrm{~ns}$ \\
$\begin{array}{l}\text { Pertambahan berat } \\
\text { badan (g/ekor) }\end{array}$ & $1.378,00^{\mathrm{a}}$ & $1.298,00^{\mathrm{ab}}$ & $1.270^{\mathrm{abc}}$ & $1.210^{\mathrm{bc}}$ & $1.178^{\mathrm{c}}$ & $* *$ \\
$\begin{array}{l}\text { Konversi Ransum } \\
\text { Karkas (\%) }\end{array}$ & $2,28^{\mathrm{a}}$ & $2,39^{\mathrm{ab}}$ & $2,45^{\mathrm{ab}}$ & $2,60^{\mathrm{b}}$ & $2,61^{\mathrm{b}}$ & $*$ \\
IOFC (Rp) & 65,14 & 68,84 & 68,80 & 67,95 & 67,99 & $\mathrm{~ns}$ \\
$\begin{array}{l}\text { Lemak Abdomen } \\
(\%)\end{array}$ & $14.270,10$ & $13.080,71$ & 12.481 .1 & 11.396 .86 & 11.085 .8 & $\mathrm{~ns}$ \\
\hline
\end{tabular}

Keterangan : Superskrip yang diikuti dengan huruf kecil yang bebeda pada kolom yang sama menunjukkan perbedaan yang sangat nyata $(\mathrm{P}<0,05)$ antar perlakuan.

\section{Konsumsi Ransum}

Tabel 4 memperlihatkan bahwa rataan konsumsi ransum ayam broiler selama penelitian menunjukkan pengaruh yang tidak nyata $(\mathrm{P}>0,05)$. Penggunaan tepung limbah biji durian fermentasi dalam ransum sampai taraf 15 persen sebagai pengganti sebagian jagung dalam susunan 
ayam broiler tidak menyebabkan penurunan terhadap konsumsi ransum. Hal ini diduga karena imbangan nutrisi terutama energi antar perlakuan adalah sama. Wahju (2004) yang menyatakan bahwa tinggi rendahnya konsumsi ransum ayam broiler dapat dipengaruhi oleh kandungan energi dalam ransum yang dikonsumsi. Penelitian ini menggunakan 21-22 \% protein dengan kandungan energi metabolisme $3000-3100 \mathrm{Kkal} / \mathrm{kg}$ yang berrarti telah dapat memenuhi kebutuhan protein dan energy ayam broiler. Menurut (SNI, 2006; Ustomo, 2016) kebutuhan untuk broiler fase finisher adalah 18 $21,2 \% \mathrm{PK}$ dan $2900-3400 \mathrm{Kkal} / \mathrm{kg}$ energi metabolis.

Penggunaan tepung limbah biji durian fermentasi dalam ransum ayam broiler tidak menggangu jumlah konsumsi ransum yang disebabkan oleh bahan fermentasi tidak menurunkan palatabilitas. Menurut Munaji (2015) Produk fermentasi umumnya tidak mengandung rasa, selain itu cita rasa ransum penelitian tidak berpengaruh pada konsumsi ransum ayam broiler, karena rasa pada unggas kurang berpengaruh terhadap rangsangan pusat lapar.

\section{Pertambahan Berat Badan}

Hasil analisis ragam menyatakan bahwa perlakuan pemberian tepung limbah biji durian dalam ransum sampai taraf $15 \%$ berpengaruh sangat nyata $(\mathrm{P}<0,01)$ terhadap pertambahan berat badan. Terjadi penurunan pertambahan berat badan seiring ditambahnya level penggunaan tepung limbah biji durian fermentasi.

Peningkatan penggunaan tepung biji durian fermentasi dalam ransum meningkatkan jumlah $\mathrm{HCN}$ yang bersifat racun bagi ayam broiler yang dapat mengganggu proses metabolisme didalam tubuh. HCN tepung biji durian kukus selama 10 menit yang dilaporkan (Rita et all., 2014) adalah 44,39 ppm. Sejalan dengan pendapat Wiradisastra (1993) bahwa pemanasan dengan uap air pada biji lupins dalam waktu yang singkat (15 menit) menghasilkan nilai gizi yang lebih baik dibandingkan waktu yang lama (lebih 30 menit), waktu pemanasan yang optimum adalah antara 15-30 menit. Bila kurang dari 15 menit antinutrisi dan faktor pembatas masih aktif sedangkan pemanasan yang lebih dari 30 menit menyebabkan terjadinya kerusakan zat-zat makanan antara lain karbohidrat.

Sinurat (1994) melakukan upaya untuk mengurangi pengaruh zat antinutrisi ini dengan teknologi fermentasi dengan A. niger. Dilaporkan bahwa produk fermentasi tepung daun singkong dapat digunakan hingga $10 \%$ dalam ransum ayam broiler yang sebelumnya hanya disarankan 5\% untuk penggunaan tepung daun singkong tanpa fermentasi dalam ransum ayam broiler, Hal ini menunjukkan bahwa daun singkong mengandung zat anti nutrisi (sianida dan serat kasar tinggi) yang dapat membatasi penggunaannya dalam ransum ternak unggas.

Pertambahan berat badan dapat dihubungkan dengan kandungan total asam amino yang terdapat pada tepung biji durian yaitu terjadi perbedaan yang nyata antar perlakuan dengan angka perlakuan kontrol adalah $6,07 \%$ dan $5,02 \%$ pada perlakuan dengan Saccaromyces cerevicae 0,75\%. Wahju, (2004) menyatakan bahwa apabila ransum kekurangan protein atau bagian asam amino esensial akan menyebabkan turunnya produksi dan ayam akan kehilangan berat badan.

\section{Konversi Ransum}

Hasil analisis ragam menunjukkan perlakuan berpengaruh nyata $(\mathrm{P}<0,05)$ terhadap nilai konversi ransum. Hasil uji DMRT terhadap angka konversi ransum menunjukkan bahwa penggunaan tepung limbah biji durian fermentasi sebanyak 7,5 dan 10 persen (F1 dan F2) didapatkan konversi ransum yang sama dengan kontrol tanpa biji durian fermentasi (F0), tetapi penggunaan limbah biji durian fermentasi sebanyak 12,5 dan 15 persen (F3 dan F4) menyebabkan konversi 
ransum nyata meningkat. Ini berarti ransum menjadi tidak efisien karena lebih banyak ransum yang dibutuhkan untuk menghasilkan satu satuan kilogram bobot badan.

Konversi ransum merupakan perbandingan antara jumlah ransum yang dikonsumsi oleh ayam broiler dengan pertambahan bobot badan yang dihasilkan. Konversi ransum merupakan salah satu indikator keberhasilan usaha bagi peternak. Tabel 5 memperlihatkan bahwa konversi pakan pada F0, F1, F2, F3 dan F4 secara berurutan sebesar 2,28, 2,39, 2,45, 2,60 dan 2,61. Penelitian Santoso (2002) menunjukan bahwa konversi pakan pada ayam broiler selama lima minggu pada kandang litter sebesar 1,6. Hasil yang diperoleh pada penelitian ini lebih tinggi disebabkan oleh masa pemeliharaan sampai dengan 6 minggu. Menurut Lesson (2000), semakin dewasa ayam maka nilai konversi pakan akan semakin besar.

Peningkatan nilai konversi ransum dapat juga disebabkan oleh suhu kandang yang tinggi, selama penelitian rata-rata suhu kandang adalah $24-31^{\circ} \mathrm{C}$, sesuai dengan pendapat Yulma, (2014) Konversi ransum pada saat penelitian lebih tinggi dibandingkan dengan standar, dapat disebabkan oleh kualitas pakan, kandungan nutrisi dalam pakan dan temperatur yang tinggi selama pemeliharaan yaitu mencapai $31^{\circ} \mathrm{C}$.

Konsumsi ransum pada masingmasing perlakuan tidak berbeda satu dengan lainnya namun mempunyai pertambahan bobot badan yang semakin rendah. Rataan nilai konversi ransum berkisar 2,28-2,61. Buruknya nilai konversi pada perlakuan $15 \%$ tepung limbah biji durian fermentasi karena jumlah konsumsi ransum tidak diimbangi dengan pertambahan bobot badan. Hasil penelitian ini sama denga penelitian Ujianto et al., (2005) yang melaporkan bahwa konversi ransum semakin rendah sejalan dengan peningkatan penggunaan kulit pisang fermentasi dalam ransum, dengan rataan konversi ransum 1,69-2,23.

\section{Persentase Karkas}

Hasil analisis ragam menunjukkan perlakuan penggunaan teoung limbah biji durian sampai level $15 \%$ tidak berpengaruh nyata $(\mathrm{P}>0.05)$ terhadap bobot karkas. Persentase karkas tertinggi diperlihatkan oleh perlakuan F1 $(68,84 \%)$ dan persentase karkas terendah diperlihatkan perlakuan F0 $(65,14 \%)$.

Ransum dengan penggunaan tepung limbah biji durian fermentasi tidak memberikan pengaruh yang nyata terhadap persentase karkas dikarenakan bahan pakan hasil fermentasi tidak mengganggu penyerapan ransum oleh ayam broiler. Siti et al., (2011) menyatakan hasil analisis sidik ragam menunjukkan bahwa tingkat penggunaan dedak padi hasil fermentasi oleh Aspergillus ficuum dalam ransum tidak mempengaruhi persentase bobot karkas.

Persentase karkas adalah gambaran dari pertumbuhan jaringan dan tulang. Semakin tinggi bobot karkas, pertumbuhan jaringan daging dan tulang yang termasuk dalam komponen karkas semakin tinggi, ini berarti bahwa semua ransum perlakuan yang digunakan berkualitas cukup baik.

Hasil penelitian ini memperoleh rataan persentase karkas berkisar 65,14$68,84 \%$. Nilai ini mendekati hasil penelitian Subekti, et all (2012) yaitu sebesar 72,98-76,26\%. Siregar (1980), menyatakan persentase karkas ayam broiler umur 6 minggu berada antara 65$75 \%$.

\section{Income Over Feed Cost (IOFC)}

Analisis Income Over Feed Cost (IOFC) ditunjukan untuk melihat keuntungan dari pendapatan yang diterima dalam beternak ayam broiler. Harga ransum dihitung berdasarkan harga yang berlaku saat penelitian, sedangkan perbedaan harga ransum yang timbul ditentukan oleh presentase atau komposisi 
bahan penyusun ransum percobaan masing-masing perlakuan. Biaya pakan dihitung berdasarkan rataan pakan yang dikonsumsi per fase dikalikan dengan harga pakan.

Hasil analisis ragam menunjukkan bahwa penggunaan tepung biji durian fermentasi pada ransum tidak memberikan pengaruh nyata $(\mathrm{P}>0,05)$ terhadap rata-rata konsumsi pada beberapa level pemberian (Tabel 4). Berdasarkan Tabel 4 didapatkan IOFC tertinggi pada perlakuan tanpa tepung biji durian fermentasi yaitu sebesar Rp 14.270,10 ; penambahan tepung biji durian fermnetasi 7,5\% sebesar Rp. 13.080,71; penambahan tepung biji durian fermentasi $10 \%$ sebesar Rp. 12.481.11; penambahan tepung biji durian fermentasi $12,5 \%$ sebesar Rp. 11.396.86; dan penambahan tepung biji durian fermentasi $15 \%$ sebesar Rp. 11.085.83. Semakin tinggi level penambahan tepung biji durian fermentasi menurunkan nilai IOFC, hal ini dikarenakan berat badan akhir ayam yang semakin turun, sehingga hasil penjualan hidup semakin kecil. Hasil ini juga berbanding lurus dengan nilai konversi ransum yang semakin tinggi seiring dengan penambahan level penggunaan tepung biji durian fermentasi, sehingga mengakibatkan biaya pakan yang tinggi. Hal ini sesuai dengan penelitian Tasa et all., (2002) yang menyatakan bahwa nilai IOFC ayam broiler yang diberi pakan dengan bentuk mash lebih rendah dibandingkan dengan ayam broiler yang diberi pakan menggunakan crumble ditinjau dari banyaknya pakan yang terbuang sehingga pengeluaran pakan tinggi.

\section{KESIMPULAN}

Berdasarkan hasil penelitian dapat disimpulkan bahwa :

1. Tepung biji durian fermentasi digunakan sebanyak $10 \%$ sebagai pengganti jagung.

2. Penggunaan tepung biji durian sebanyak 7,5\%-15\% menurunkan lemak abdominal.
3. Penggunaan tepung limbah biji durian fermentasi dalam ransum broiler sampai taraf $15 \%$ tidak mempengaruhi profil hematologi

\section{DAFTAR PUSTAKA}

Arsepto, 2004. Pemanfaatan Tepung Biji (Durio zibethinus Murr) sebagai Sumber Energi dalam Ransum Ayam Broiler. Tesis Pascasarjana. Universitas Padjadjaran. Bandung.

Ciptadi, W dan Z. Nasution. 1980. Pengolahan Ubi Ketela Pohon. Departemen Teknologi Pengolahan Hasil Pertanian. Fatameta. IPB Bogor.

Dinas Peternakan Provinsi Bengkulu. 2013. Populasi Unggas Menurut Kabupaten/Kota dan Jenis Ternak di Bengkulu (Ekor). Bengkulu

Lesson, S. 2000. Feed efficiency still a usefull measure of broilers performance. Department Animal and Poultry Science. University of Guelph, Ontario.

Munaji D.A., Nuraini dan Amiluddin Indi. 2015. Pengaruh Pemberian Dedak Padi Fermentasi Terhadap Pertumbuhan Ayam Broiler. Jitro Vol.2.No.1

Rita, W., Sunaryadi, dan L. Malianti. 2014. Pemanfaatan Tepung Biji Durian (Durio zibethinus Murr) dan Suplementasi Mineral Proteinat dalam Ransum terhadap Performan Ayam Broiler. Laporan Penelitian Hibah Bersaing. Universitas Muhammadiyah Bengkulu.

Sinurat, A.P., 1994. Penggunaan Bahan Pakan Lokal Dalam Pembuatan Ransum Ayam Buras. Wartazoa 9 (1) : 12-20.

Siregar, A., P.M. Sabrani., dan P. Suprawiro. 1980. Teknik Beternak Ayam Pedaging Di Indonesia. Penerbit Margie Group, Jakarta.

Siti, W. H.S., Dwi, C.P. Heri, S. Suliantari. 2011. Respon Broiler Terhadap 
Pemberian Ransum Mengandung Dedak Padi Fermentasi oleh Kapang Asfergillus Ficuum. Jurnal Ilmu Ternak No.10 Vol.1, 26-3

Steel, R.G.D. dan J.H. Torrie. 1991. Prinsip dan Prosedur Statistika Suatu Pendekatan Biometrik. Edisi Kedua. Penerbit PT Gramedia Pustaka Utama. Jakarta.

Tasa, A., M. Z. Mide dan E. J. Tandi. 2002. Income Over Feed Cost and Chick Cost Ayam Broiler yang Diberi Ransum Mash dan Crumble.
Bulletin Nutrisi dan Makanan Ternak. 3(2): 1-13.

Udjianto A, Rostianti E, Purnama DR. 2005. Pengaruh pemberian limbah kulit pisang fermentasi terhadap pertumbuhan ayam pedaging dan analisa usaha.Prosiding Temu Teknis Nasional Tenaga Fungsional Pertanian, Bogor 2005.Pp 76-81.

Wahju, J. 2004. Ilmu Nutrisi Unggas. Cetakan Kelima. Gadjah Mada University. Press. Yogyakarta. 